\title{
Multimedia application's positive analysis on university music education
}

\author{
Zhangfengfeng \\ Xuchang university, Xuchang,China, 461000
}

\begin{abstract}
Keywords: Multimedia; Music teaching, Organization and management
\end{abstract}
\begin{abstract}
This paper discusses multimedia platform's positive analysis on university music education, mainly discusses the concept and characteristics of multimedia platform, analyzes music teaching design theory and performs feasibility analysis on how to apply multimedia to university music teaching. This paper designs music curriculum model based on multimedia teaching platform, discusses the organization and management of music curriculum in multimedia teaching platform, curriculum implementation and curriculum evaluation mode. Practices prove that the use of multimedia platform for teaching can not only change students' music study way, but promote students' innovation ability. Teachers can both make full use of high-tech means in music teaching and develop students' music learning space, enhance learning effect, and promote teaching optimization.
\end{abstract}

\section{Introduction}

Since human step into information society at the end of 20 century, the rapid development of computer science, especially the emergence of multimedia technology and network technology have changed the operation and development models in every field of the society and social members' way of life and education mode. "Knowledge economy" and "information society" are increasingly becoming important concepts of attention, which give birth to the new education adapting to information civilization and information social services: informationized education. Informationized education is modern information technology widely used in various fields of each department and teaching activities of education, which effectively develops and utilizes information resources, fast, conveniently and accurately transmits information resources to achieve resource sharing and greatly improve education quality, teaching efficiency and innovation ability [1]. The emergence of multimedia and the application in music teaching realize the effective integration of information technology and music course, which facilitates convenient dissemination of information, improves music teaching effect and quality, and gives full play to the students' cooperative learning music ability and innovation ability. As auxiliary means of music teaching, multimedia used by teachers in music teaching in network learning environment is a new attempt of multimedia applications, specifically including the application of multimedia in teaching design of music curriculum, the use of multimedia in music extracurricular counseling design, or hybrid application of multimedia technology nested in music teaching platform and so on. Although multimedia has been widely used in music teaching, it also exposes some problems in use. First of all, multimedia is simple and convenient, but a lot of users are hard to hold on, Second, there are not many multimedia with thought and connotation; In addition, most of domestic multimedia don't use TrackBack technology [2 4] which causes limited communication range and becomes an "information island"; Overseas, a lot of famous experts and scholars spread knowledge through multimedia, share their experience in scientific research, while in domestic, these experts and scholars are not many [5].

\section{Music teaching platform's course design model based on multimedia}

This paper puts forward a music teaching platform's course design model based on multimedia. Firstly, analyze music learners and music teaching contents, then determine the specific music teaching goal, and complete component design of all music teaching designs. The analysis of music leaners and teaching contents is to lay the foundation of determining the teaching goal. And the 
determining of teaching goal is the starting point and the core of various teaching compositions. Each component design of teaching design will be spread around teaching target. Specific teaching design components include teaching environment design, teaching strategy choice and so on; Each instructional design component influences each other. While designing a teaching design component, another teaching design component can be used crossover. The next step is the stage of course implementation and management. The last is the overall design of the evaluation process, which is to evaluate if each teaching design component meets the requirements of the teaching goal. Evaluation conclusion is directly used to modify the design results. Evaluation standard is an indicator system constituted from teaching goal. Evaluation results will be used in final modification of curriculum design.

Music course evaluation. Music course assessment is a value judgment of teaching results. It directly acts on all aspects of music teaching activities and is an important part of music teaching. Evaluation is to test music teaching results, find out problems in teaching, indicate the direction of music teachers' teaching improvement, and at the same time provide guidance for students to adjust music study strategy.

Based on education purpose, teaching goal requirements, music teaching evaluation is to describe and determine music teaching effect according to certain rules in order to check and promote teaching and learning. Its essential function is to promote the development of students. And music teaching design based on constructivism is a dynamic development process. This needs organic combining of evaluation, music teachers' teaching and students' music knowledge construction process. Bring evaluation into students' initiative knowledge construction process in order to promote students' music learning and self-development. Therefore, it pays more attention to the formation and development of sentiment attitude and value concept and students' change in knowledge construction. Music teaching evaluation based on constructivism has several functions: feedback and adjustment, motivation and promote, reflection and summary, growth process record and actively guiding and so on. Its contents include the evaluation, cooperation consciousness and ability evaluation of students actively participation in music teaching activity degree, and the evaluation of finding problem, putting forward problem and solving problem processes.

Music teaching evaluation mode. In music teaching evaluation, different conventional ideas and methods should be given enough attention and positive evaluation. Music course evaluation adopts diversified ways of evaluation. Classroom teaching evaluation partly uses written test way; In practice, use assignments performance evaluation and practical ability's practice assessment. Of course assignments performances are mainly students' self evaluation, mutual evaluation in groups, evaluation between groups, teachers' evaluation and so on. Evaluation methods in the research are mainly Portfolio Assessment, gauge table evaluation and written test ways.

1. Portfolio Assessment is to organized present all relevant data to achieve a certain purpose in a certain process. Through these material or stuff, it can show the progress of the process or personal growth experience. Gardner argues that Portfolio Assessment is a continuous and natural evaluation form to encourage students to become active learners aware of their learning and personal development. Implementing "student growth record bag" evaluation method is education evaluation reform advanced in the new curriculum background, which gives full play to the education evaluation guide, diagnosis, regulation, motivation, reflection, and other functions, sets up specific measures to promote students comprehensive development assessment system. "Students' growth record bag" is a quality evaluation and a development evaluation, which is also a student-oriented evaluation. In this application practice, respect students opinions, record the feelings and experiences in the whole learning process with multimedia to share with classmates conveniently. We make links of students' multimedia for all to share the happiness and joy of study.

2. Gauge table evaluation has a circulating and stimulative role. Its basic idea is to use cognitive analysis method in describing learners' mechanisms of gaining different knowledge. Based on it, design all kinds of tests to measure and evaluate knowledge changes or knowledge construction process in learners' mind. So teaching and measurement, evaluation are organically combined together to make people see the circulating and stimulative effect between them. Gauge table is used 
to respectively implement self evaluation, seeking collaborator or students self evaluation, or group evaluation, seeking teachers evaluation, and sometimes parents evaluation or social evaluation, etc.

3. Written test way of evaluation. Written test is the evaluation of students' independent learning process, which is especially an effective form of thinking process evaluation. Students independent learning processes needs experience exploring, speculation or conjecture and effective reasoning to solve the relevant problems. Therefore, students independent learning process is mainly embodied in the process of finding problems, putting forward problems and solving problems and in the process of experience inquiry finding knowledge. But if written test is to properly evaluate students' independent learning process, it is necessary to change test form and test question types. The test form can combine closed-book exam and open-book exam. Test question types are divided into closed-book type and open-book type.

Teaching evaluation is an indispensable basic link in teaching activity, is the last step in the whole teaching design process and plays many roles in the teaching process. Teaching evaluation adjusts and controls teaching activities as a whole, ensures teaching activities advance toward the intended target, and finally reaches the requirements of teaching goal. Multimedia teaching design evaluation may evaluate according to education objectives, curriculum design, teaching effect, students' learning effects and final learning quality and other information. Only through various ways of evaluation can more accurately grasp teaching results and further develop teaching activities. According to the above principles, the author designed evaluation gauge table based on multimedia teaching platform, which is shown in Table 1:

Tab 1. Multimedia evaluation gauge table

\begin{tabular}{|c|c|c|c|c|}
\hline $\begin{array}{l}\text { Evaluation } \\
\text { standard }\end{array}$ & 5 points & 4-3 points & 2-1 points & score \\
\hline teaching goal & $\begin{array}{l}\text { Based on music } \\
\text { teaching goal, course } \\
\text { design reflects music } \\
\text { teachers' leading role and } \\
\text { students' main body status. }\end{array}$ & $\begin{array}{l}\text { Curriculum design is } \\
\text { reasonable, can basically } \\
\text { achieve the teaching goal } \\
\text { request, but still needs to } \\
\text { be modified. }\end{array}$ & $\begin{array}{l}\text { Curriculum design } \\
\text { does not conform to the } \\
\text { teaching goal, and cannot } \\
\text { achieve teaching } \\
\text { requirements. }\end{array}$ & \\
\hline Teaching resources & \begin{tabular}{l}
\multicolumn{1}{c}{ Music curriculum } \\
resources have various \\
forms; Information \\
content is of the right size; \\
All links all can open; \\
Content is correct, and the \\
transition is natural.
\end{tabular} & $\begin{array}{l}\text { There are more } \\
\text { music curriculum } \\
\text { resources forms; The size } \\
\text { of information content is } \\
\text { basically right. There are } \\
\text { at most three links can not } \\
\text { open; The basic content is } \\
\text { right. }\end{array}$ & $\begin{array}{l}\text { Course resources } \\
\text { form is single; Less } \\
\text { information content; } \\
\text { There are more than three } \\
\text { links can not open; } \\
\text { Existing error content. }\end{array}$ & \\
\hline Teaching activities & $\begin{array}{l}\text { According } \\
\text { teaching needs, create a } \\
\text { good interactive } \\
\text { environment for the } \\
\text { teachers and students by } \\
\text { using rich teaching and } \\
\text { learning activities of } \\
\text { multimedia such as } \\
\text { published articles section, } \\
\text { message area, interactive } \\
\text { evaluation area, etc. }\end{array}$ & \begin{tabular}{l}
\multicolumn{1}{r}{ According } \\
teaching needs, create a \\
good \\
environment interactive \\
teachers and students by \\
using teaching and \\
learning activities of \\
multimedia
\end{tabular} & $\begin{array}{l}\text { Using less activities, } \\
\text { the communication } \\
\text { between teachers and } \\
\text { students, students and } \\
\text { students are not enough. }\end{array}$ & \\
\hline Evaluation & 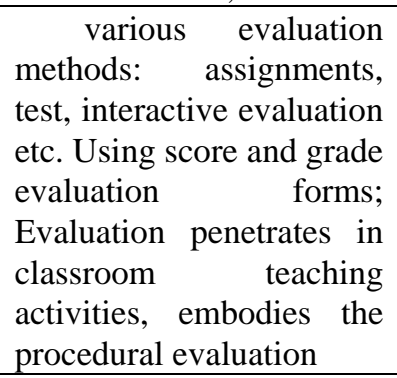 & 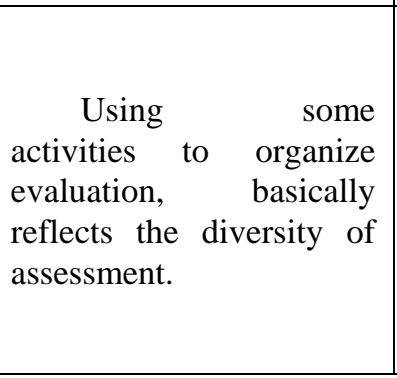 & $\begin{array}{l}\text { Evaluation method } \\
\text { is more onefold, and can } \\
\text { not comprehensively, } \\
\text { multi-angled evaluate } \\
\text { students. }\end{array}$ & \\
\hline
\end{tabular}




\section{Experimental results}

After course practice, we carry on the investigation of the students participating in the study practice. The purpose is to understand the music learning effect after students' use of multimedia teaching platform. It is the summary of this paper, and the final results of this study. Through scientific analysis, draw relevant conclusions, and provide beneficial reference to university music teaching reform. Questionnaire survey provides some default questions, which can be used to understand students' opinion, attitude, etc. In the questionnaire, the students' satisfaction degree of using multimedia teaching platform, the content of multimedia teaching platform, platform operation and finally learning results achieved are conducted detailed investigation. The results and data are shown in Table 2:

From the above investigation and statistical results, we can see that most of the students think that multimedia teaching platform is helpful for their learning, the application of multimedia teaching platform course can promote their own learning and mutual communication and coordination ability. Most students think platform interface is easy to operate and the related links can satisfy the needs and resources are abundant. Because this semester's music culture foundation course is tested by teachers organizing the exam, three aspects abilities are tested through test papers: respectively music foundation knowledge, music singing ability and skills application ability. The author teaches two classes, respectively adopts traditional classroom teaching mode and the teaching way by application of multimedia teaching platform. After the experiment, the statistics and summary of the two classes scores were conducted and found that the average scores of the test class are higher than that of the other class. Two classes scores analysis is shown in Figure 1 and 2 below:
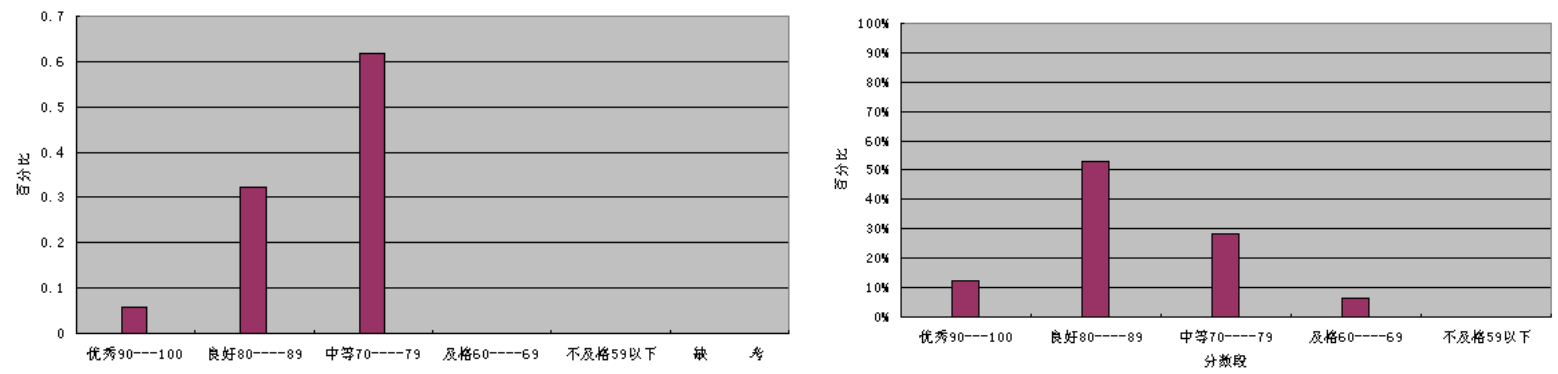

Fig 1. General teaching class scores analysis graphics Fig 2. Experimental class scores analysis graphics

Through the above two classes' performance analysis, we can see that the overall performance of the experimental class is higher than that of the other class. In the multimedia teaching experiment class grade: Excellent rate $12 \%$, good rate $52 \%$, moderate rate $28 \%$, pass rate $8 \%$; the other class grade: Excellent rate $7 \%$, good rate $32 \%$, moderate rate $61 \%$. From the distribution of scores, it can be seen that the excellent rate and the good rate of the experimental class are both higher than the other class, which means that the application of multimedia teaching platform is able to improve the students' academic performance.

\section{References}

[1] Young, A(1997). Hjgher-Order Learning and Thinking:What Is It and How Is It Taugh Educational Technology,37(7-8),40-41

[2] Allan CoUins John seely brown,and Ann Holum Cognitive Apprenticeship:Making Thinking Visible http: // www. 211earn.org /arch /artieles Porown seely.Html/30/12/2004

[3] Hannum WH. Hansen, C. Instrucitonal systems development in large organizations[M]. EnglewoodClifs,CO:Librarie Unlimited,1989

[4] Robes Heinich. InsturctionalMedia and Technologiesfor Learning[M]. (seventh edition, gravure) Beijing: Higher Education Press,2002. 